\title{
Gates of Dachau
}

Place: Entrance of Dachau Concentration Camp, southeast of Dachau, Bavaria, Germany

Photographer: David Butts

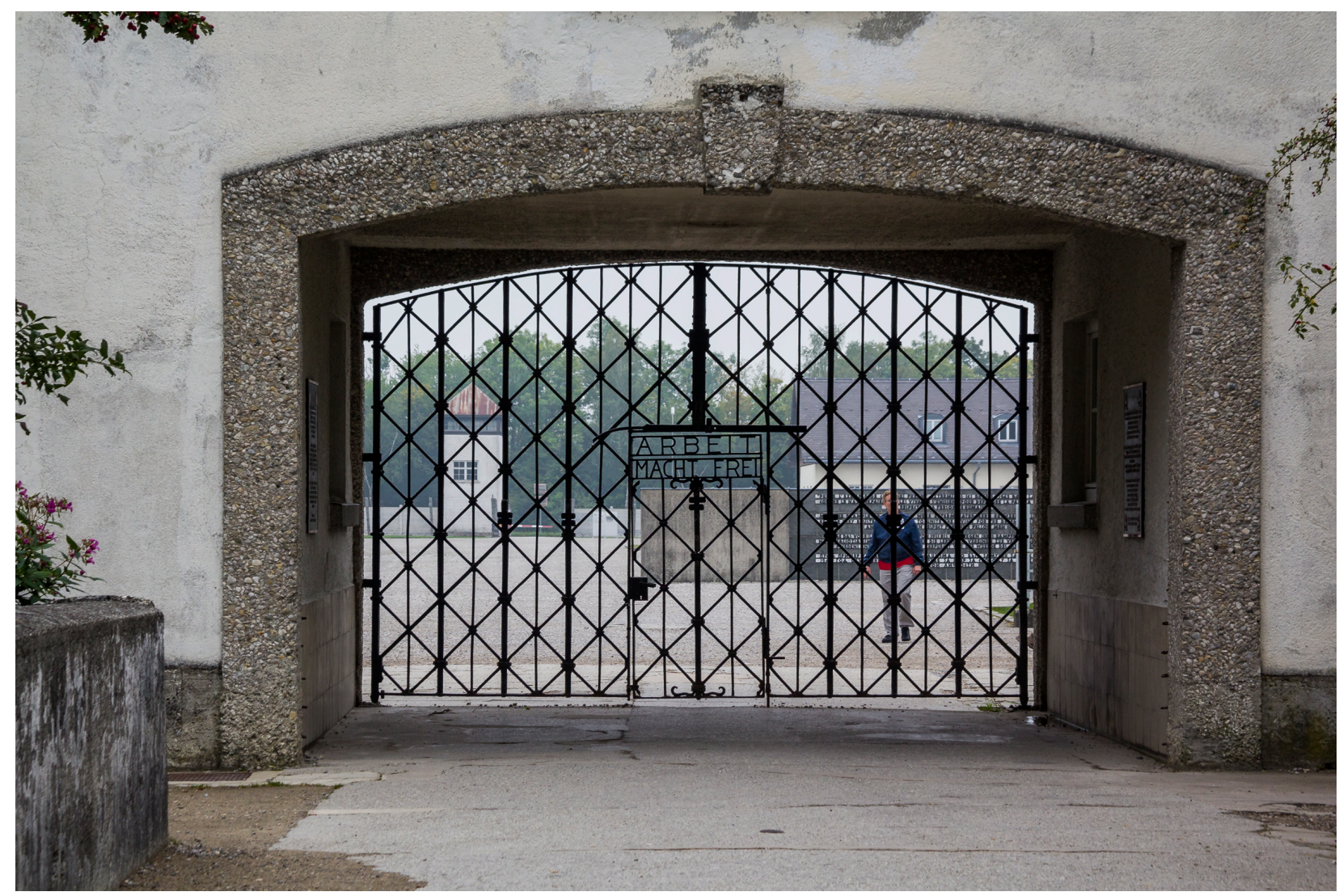

Cultural and Pedagogical Inquiry, 2015, 7(2), pp. 83 ISSN 1916-3460 (C) 2015 University of Alberta

http://ejournals.library.ualberta.ca/index.php/cpi/index 